\title{
A biophysicist in the kitchen
}

\author{
Félix M Goñi
}

\begin{abstract}
This paper originates from the reflections of a practicing biophysicist, that is, the author, while cooking at home, either everyday or at festive dinners. Both the activities, biophysics and cooking, were independently learned and incorporated into the author's life at different stages. Yet at some point, the biophysical reasoning permeated into the cooking of recipes. The biophysical interpretation of cooking has evolved to include other main subjects, such as the survival of vitalism in the mirage of 'natural food', the formalization of cooking as a pre-digestion and the democratization of good food through food technology.
\end{abstract}

Keywords: Biophysics, Biochemistry, Physical chemistry, Food technology, Cooking, Cuisine, Digestion, Vitalism

\section{Introduction}

It often happens that, when someone knows of my profession as a biophysicist and of my main domestic chore, that is, cooking, I am asked: "But, how do you cook?" I invariably detect an edge of suspicion in that question. What most of them ache to ask is: "Do you put chemistry into your cooking?" When, after a few polite exchanges, they confess to their poorly concealed real question, my reply is: "No, I don't put any chemistry into my cooking; cooking is chemistry and mostly biophysical chemistry at that." This is the main message of this paper, namely that it is a good time for vitalism to die, that there is no real difference between the chemical, biological and culinary processes, and that gastrophysics may help everybody to eat better.

\section{Science is not against traditional cuisine}

Science and cuisine are two activities which are often presented as opposing each other; cuisine would be a handcraft, kept as remote as possible from the eversuspicious activities carried out by mad, if not venal, scientists in their laboratories. Grandma's food will always be superior to any of the new concoctions. Needless to say this is a pure mirage, owing to the fantastic ability of the human mind to suppress negative aspects of our memories. In a world of no electric fridges, slow transport, very short seasons for most vegetables, when food took away a much larger fraction of family incomes

Correspondence: felix.goni@ehu.es

Unidad de Biofísica (CSIC-UPV/EHU), Barrio Sarriena s/n, Leioa, Bizkaia 48940, Spain

C Biomed Central than now, it is difficult to explain how food was so much better. In the absence of any 'time machine' experiment to take us back there, it is enough to use our memory in a more objective manner to find out that we eat, qualitatively and quantitatively, far better than our forefathers (albeit we do it in excess, but that is another problem).

Yet the nostalgia of an inexistent past fuels most of the food business today. The greengrocer will offer us 'biologically grown' lettuces, the butcher will tell us that this particular veal was fed 'naturally' and the wine supplier will boast, in all honesty, of a wine made 'without any chemistry'. In short, we believed that the death of vitalism was initiated with the 1828 synthesis of urea from ammonium cyanate by Friedrich Wöhler [1], and fully completed with the in vitro synthesis of nucleic acids by Severo Ochoa and Marianne Grünberg-Manago in 1955 [2]; but, apparently, vitalism never dies. Perhaps the 'death of vitalism' is a contradiction in itself.

The way to overcome the artificial 'science vs. cuisine' debate is through education. Only scientific education at school-level can change our children's understanding. Nowadays, none of them believes that the Earth is flat or that the Sun moves around the Earth. For the same reason, none of our fellow citizens should believe that living organisms contain components undetectable to chemical analysis.

\section{Physics and chemistry as the foundations of food technology}

It should be clear that in our age, improvements in cooking should come from the experimental sciences, 
rather than from pure empiricism or supposed folk traditions. This should be valid for both 'haute cuisine' restaurants and for collective restauration. Food technology is, in the author's opinion, in its infancy and largely devoted to the preservation of foods. This is a plausible aim but, in a society in which more people find the preparation of home-made meals impracticable and simultaneously the same people fall prey to obesity, type II diabetes and vascular diseases, food technology must make an effort to shift its main attention to food cooking, rather than to food preservation. The aim is to help all to eat better, to improve all our meals, making them appetizing and healthy.

In the pathway from empiricism to rational cooking, it is interesting to note that some of the avant-garde restaurants in the world [3,4] are already moving in this direction. Not only are physicochemical parameters (temperature, pressure, salt concentration and time) meticulously measured and respected, but also the raw materials (vegetables, fish and meat) are standardized as much as possible, the result of long and costly collaborative works with the suppliers. In this way, foods whose physical and chemical properties are almost exactly reproducible are treated in the same way, invariably giving rise to an optimum result. The famous, semi-magical point of the great chefs now gives way to technology. However, as mentioned above, the idea is that this culinary revolution does not stop at the Michelin star restaurants, but is extended to our homes, passing through schools, hospitals, prisons, convents and similar painful institutions. The motto is good food for all.

It is almost impossible in this context to avoid mentioning, at least in passing, the role of genetically modified organisms (GMOs) (plants, animals, micro-organisms) in the new food technology. The author is fully aware of the strong and active advocates against GMOs. So were the opponents to railways and to electricity. GMOs will prevail, just because they are better in so many senses, not to mention that all of our food has been genetically modified by agriculture or animal breeding in the last five millennia. When GMOs are accepted, as we accept electric light today, then the role of another science, biotechnology, will be recognized for its role in the marvelous endeavor of providing good food for all.

\section{An example: cooking as a pre-digestion}

Some of the above concepts, and particularly the oneness of chemistry and biology, are exemplified by the observation that cooking reproduces essentially the same processes occurring in food digestion [5], that cooking in some way anticipates digestion. Let us examine briefly the fate, in the kitchen and in the digestive tract, of the three most abundant components of food, namely carbohydrates, proteins and lipids.
Carbohydrates in our diet are particularly frequent in the form of starch (bread, pasta, rice, and so on). The cooking of pasta, or rice, or peas and the like, invariably includes a step of boiling. With this we can achieve two main effects. One is the hydration of the starch molecules, which are kept in the plant cell with a minimum of water to facilitate storage. The second effect is the partial hydrolysis of starch, a polysaccharide, which must be broken down into its component glucose units for intestinal absorption. But these two actions of carbohydrate cooking are essentially the same as those performed by saliva in our mouths. Insalivation moistures our bread and the saliva amylase partially breaks down the starch into smaller molecules. Cooking helps digestion, by contributing to some of its degradative steps.

The same can be said of the proteins in our diet. With a few exceptions, for example, sushi and some seafood, in which raw meats are eaten in small amounts, proteins are denatured by heat and partially hydrolyzed during cooking. Both effects are again found in digestion, this time in the stomach. In this case denaturation does not occur by heat, but by acid (the gastric juice has a $\mathrm{pH}$ as low as 1). Note incidentally that in pickled herring, to mention one example, the proteins are denatured by acid (vinegar), just as it is done in the stomach by hydrochloric acid. Denaturation is meant to facilitate degradation to peptides and ultimately to amino acids, to be absorbed in the intestine. Cooking, especially cooking by heat, causes partial hydrolysis of proteins by activating proteases present in the cell lysosomes. In digestion, enzymes like pepsin, which can work under extremely acidic conditions, perform the partial hydrolysis of proteins in the stomach. It can be mentioned in this context that the food combination of meat with pineapple (Hawaii) or meat with papaya (Brazil) are excellent examples of this point. Both pineapple and papaya contain protease enzymes, respectively bromelain and papain, which are active at the low $\mathrm{pH}$ of the stomach, so these food combinations are somehow providing extra digestive power.

The case of fats is equally interesting. The primary enzymes involved in fat digestion are the lipases in the small intestine. However, lipases can only act in an aqueous environment. Therefore, fats must be fragmented into tiny particles, usually by mixing with non-fat substances, giving rise to microscopic droplets or micelles, amenable to digestion by lipases. In the small intestine, fat fragmentation (emulsion) is achieved by a special brand of detergents, the so-called bile salts, produced by the liver. Bile salts combine with the water-insoluble fats to produce a stable aqueous dispersion or emulsion of bile salt/fat-mixed micelles. The only source of fat in infancy, and a large source of fat for many humans throughout their lives, is milk. Milk is said to be easily digested. In fact, milk is a natural emulsion of fat in 
water, stabilized this time by proteins instead of bile salts. The cooking of fats normally includes their emulsion. Typical culinary emulsions are mayonnaise and béarnaise sauces, of a very complex physical chemistry. In the Basque Country, several fish preparations of cod and hake include sauces, which consist of olive oil and water emulsions stabilized by the fish proteins. In short, cooking anticipates the digestive fate of fats, that is emulsions, prior to their degradation and absorption in the small intestine.

This discussion probably explains the enormous evolutionary advantage of cooking for humans. Cooking is a purely human activity. The energy and time required to eat and digest cooked meals are much less than in the case of raw foods. Cooking liberated mankind for other activities, in addition to facilitating its feeding, the limiting step in animal reproduction. It is not an exaggeration to say that cooking has, to a large extent, made us human.

\section{A future for gastrophysics}

In conclusion, there is a need for a novel science, which has been called gastrophysics, and could be defined as the study of cooking on the basis of biophysical and physicochemical methods and paradigms. Gastrophysics will be aimed at:

- interpreting cooking in physical and chemical terms,

- conducting novel research within the above framework, and

- providing better food for all.

\section{Abbreviation}

GMO: Genetically modified organism.

\section{Competing interests}

The author declares that he has no competing interests.

Received: 14 November 2012 Accepted: 15 November 2012

Published: 9 January 2013

\section{References}

1. Wöhler F: Ueber künstliche Bildung des Harnstoffs. Annalen der Physik und Chemie 1828, 88:253-256.

2. Grunberg-Manago M, Oritz PJ, Ochoa S: Enzymatic synthesis of nucleic acid-like polynucleotides. Science 1955, 122:907-910.

3. Berasategui M, Alija JAM: Cocina del Restaurante Guggenheim Bilbao. Navarra: MAB Press; 2004.

4. Adria F, Adria A: A Day at elBulli: An Insight into the Ideas, Methods and Creativity of Ferran Adria. London: Phaidon Press Ltd; 2010.

5. Goñi FM: Un bioquímico en la cocina. Revista SEBBM 2010, 166:20-24.

doi:10.1186/2044-7248-2-7

Cite this article as: Goñi: A biophysicist in the kitchen. Flavour 2013 2:7.

\section{Submit your next manuscript to BioMed Central and take full advantage of:}

- Convenient online submission

- Thorough peer review

- No space constraints or color figure charges

- Immediate publication on acceptance

- Inclusion in PubMed, CAS, Scopus and Google Scholar

- Research which is freely available for redistribution 